\title{
Unorden
}

SEKTORPROGRAM

\section{Undervisning og forskning, kultur, børn og unge}

Islands formandskab i Nordisk Ministerråd 2014

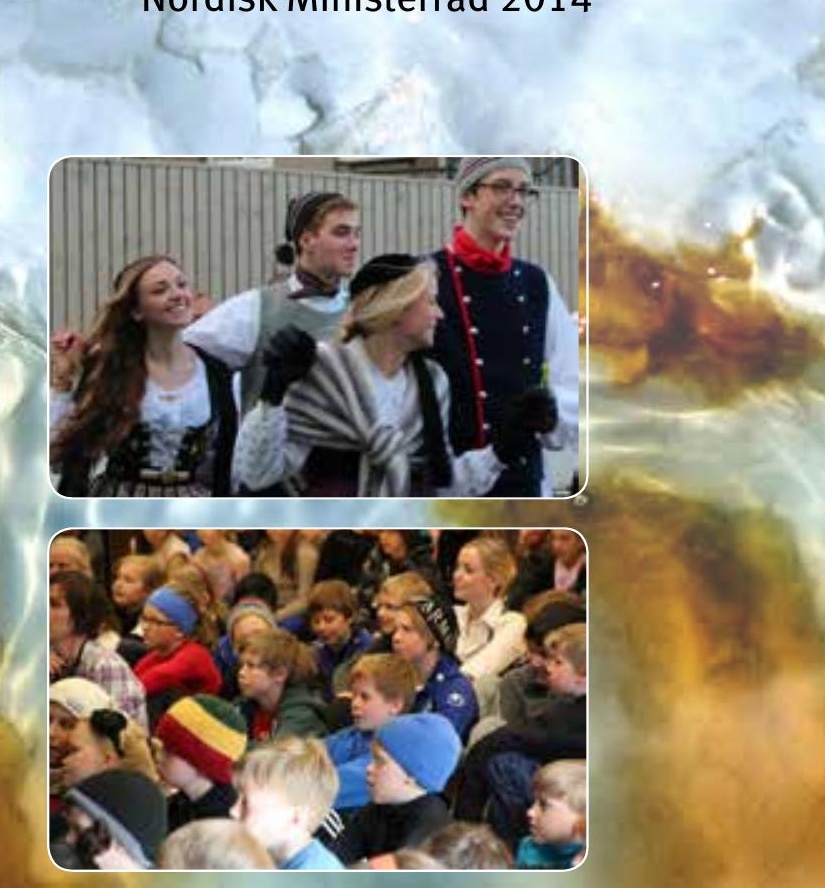




\section{Undervisning og forskning, kultur, børn og unge}

Sektorprogram for Islands formandskab i Nordisk Ministerråd 2014

ISBN978-92-893-2733-6

http://dx.doi.org/10.6027/ANP2014-716

ANP2014:716

(C) Nordisk Ministerråd, København 2014

Design: Jette Koefoed

Fotos

Omslag: Einar Ólason/Undervisnings-, forsknings- og kulturministeriet

s. 4: Freysteinn Sigmundsson, Nordisk Vulkanologisk Center

s. 7: Anna Margrét Guðjónsdóttir

s. 15: Undervisnings-, forsknings- og kulturministeriet

s. 19: Biophilia

s. 25: Porbjörg Ágústsdóttir, Nordisk Vulkanologisk Center

Oplag: 400

Skrift: Meta LF

Papir: Munken Polar

Tryk: Rosendahls-Schultz Grafisk

Printed in Denmark

\section{Det nordiske samarbejde}

Det nordiske samarbejde er en af verdens mest omfattende regionale samarbejdsformer. Samarbejdet omfatter Danmark, Finland, Island, Norge og Sverige samt Færøerne, Grønland og Åland.

Det nordiske samarbejde er både politisk, økonomisk og kulturelt forankret, og er en vigtig medspiller i det europæiske og internationale samarbejde. Det nordiske fællesskab arbejder for et stærkt Norden i et stærkt Europa.

Det nordiske samarbejde ønsker at styrke nordiske og regionale interesser og værdier i en global omverden. Fælles værdier landene imellem er med til at styrke Nordens position som en af verdens mest innovative og konkurrencedygtige regioner.

\section{Nordisk Ministerråd}

Ved Stranden 18

DK-1061 København K

Telefon (+45) 33960200

\section{www.norden.org}




\section{Undervisning og forskning, kultur, børn og unge}

Islands formandskab i Nordisk Ministerråd 2014

\section{Indhold}

4 Forord

6 Islands formandskabssatsninger 2014

8 NORDBIO - Nordisk bioøkonomi

9 Biophilia projekter

14 Undervising og forskning

22 Kultur

29 Børn og unge 


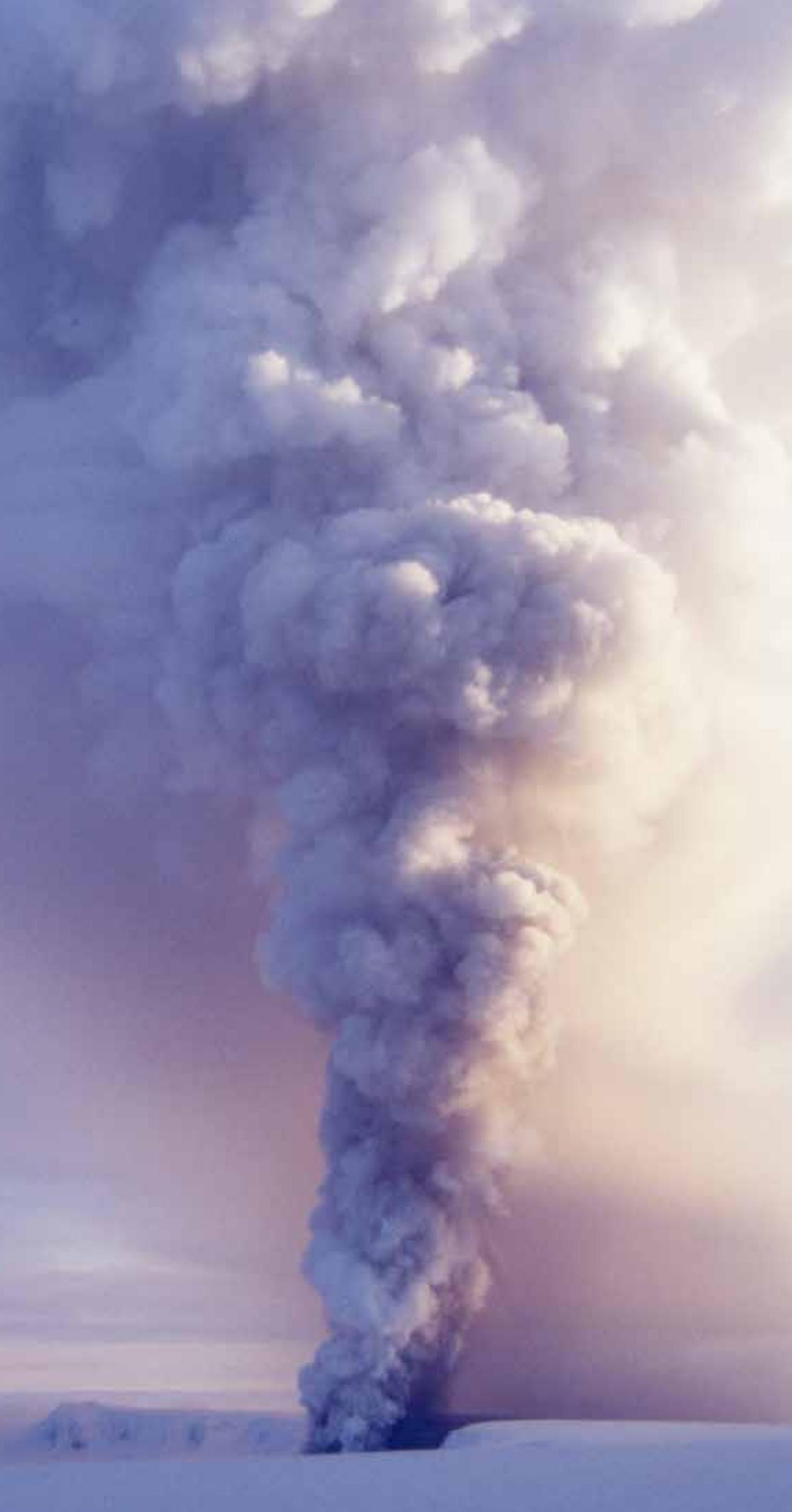




\section{Forord}

Det islandske formandskabs prioriteringer bygger på Nordisk Ministerråds prioritet om Grøn Vækst, programmet Holdbar Nordisk Velfærd, strategier og handlingsplaner om kultursamarbejde, uddannelse og forskning samt børn og unge. I Nordisk Ministerråds arbejde er der lagt vægt på en harmonisering og kontinuitet, og derfor tager vores formandsskabsprogram også hensyn til det svenske formandsskabsprogram for 2013 og resultatet af samrådet indenfor Nordisk ministerråd vedrørende prioriteringer for de næste år.

Det nordiske samarbejdes styrke består blandt andet i dets evne til at arbejde med tværfaglige opgaver og derfor fremlægges der et fælles formandsskabsprogram indenfor kultur, undervisning og forskning. Man vil forsøge at forene prioriteringer på disse områder med hensyn til kreativitet og skaberkraft som vej til fornyelse og initiativ.

Bioøkonomi får højeste prioritering i det islandske formandskabsår og bygger på samarbejde inden for mange områder. På områderne kultur, undervisning, forskning og børn og unge er der lagt vægt på det tværfaglige projekt Biophilia, kreativitet som undervisnings- og forskningsmetode.

Det nære samarbejde mellem de nordiske lande er enestående og har været et forbillede for mange andre lande. I den forbindelse kan man nævne samarbejdet mellem de baltiske lande og det kulturelle samarbejde mellem staterne i det tidligere Jugoslavien. Islændingene vil forsvare dette samarbejde og udbygge det videre, for det bygger på vores fælles kultur og demokratiske værdier.
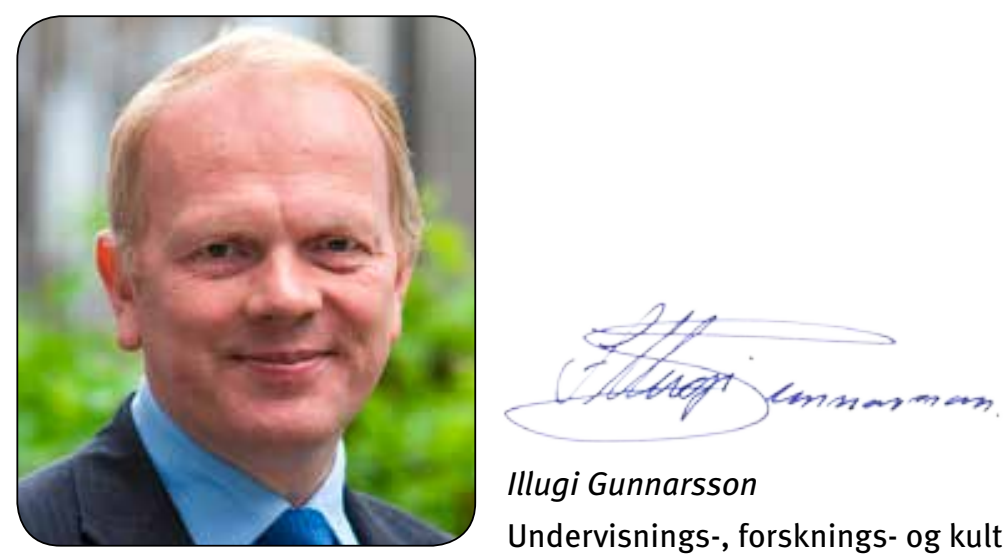

Illugi Gunnarsson

Undervisnings-, forsknings- og kulturminister 


\section{Islands formandskabssatsninger 2014}

Grokraft - livskraft er overskriften på Islands formandskabssprogram for det nordiske samarbejde indenfor Nordisk Ministerråd i 2014. Denne overskrift danner grundlaget for de tre initiativer, som Island prioriterer under sit formandskab.

- Med Nordisk biøkonomi - NordBio - vil man bl.a. finde metoder til at udnytte vores biologiske ressourcer på en effektiv måde. I den henseende og for at sikre en grøn økonomisk vækst og en bæredygtig udvikling $\mathrm{i}$ fremtiden, er det vigtigt at koble Nordisk bioøkonomi til undervisning og forskning. Der lægges vægt på at forbinde disse områder med initiativer, hvor kreativitet bliver brugt som undervisnings- og forskningsmetode under definitionen Biophilia.

- Med Nordisk velfærdsvagt vil Island sætte fokus på den nordiske velfærdsstats modstandskraft og dens evne til promte at reagere på kriser, når de indtræffer med kort varsel. Velfærdsvagten skal blandt andet indsamle og udvikle velfærdsindikatorer, der kan bruges som basis for nye indsatser og strategier for velfærdsområdet i de nordiske lande.

- Med projektet Nordic Playlist vil Island arbejde for at styrke det nordiske marked for populærmusik, gøre opmærksom på nordiske kunstnere og grupper, øge eksportmulighederne for nordisk musik, registrere nordisk populærmusik i takt med dennes udvikling samt drage nytte af det nordiske samarbejdes potentiale på området. 


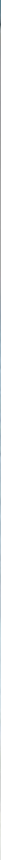

UNDERVISNING OG FORSKNING, KULTUR, BøRN OG UNGE - ISLANDS FORMANDSKAB 2014 


\section{NORDBIO - Nordisk bioøkonomi}

Under sit formandskab i 2014 vil Island fokusere på at styrke det nordiske samarbejde omkring nye initiativer med et tværsektorielt samarbejde inden for forskning, udvikling og innovation. Dette skal ske i et tæt samarbejde og i dialog med industri og undervisningsinstitutioner. For at arbejde med dette oprettes der et nyt nordisk program: Nordisk bioøkonomi - NordBio.

Nordisk bioøkonomi er et treårigt samarbejdsprogram 2014-2016 mellem ministerrådene for fiskeri, havbrug, jordbrug, levnedsmidler og skovbrug (MR-FJLS), som er hovedansvarlige for programmet, og ministerrådene for miljø (MR-M), erhvervs-, energi- og regionalpolitik (MR-NER), uddannelse og forskning (MR-U) samt kultur (MR-K), som er delansvarlige for programmet.

Eksperter på disse områder vil forene deres kræfter og samarbejde om projekter som bidrager til en bæredygtig udnyttelse af levende ressourcer. Man vil fokusere på samfundets og miljøets interesse og bidrage til opbygningen af et konkurencedygtigt erhvervsliv og udviklingen af nye undervisningsmetoder.

\section{Formålet for NordBio}

At udvikle og forbedre metoder for en bæredygtig produktion og udnyttelse af råvarer med det formål at stimulere innovation og erhvervsliv samt at reducere miljøbelastninger i de nordiske lande.

- At styrke viden og underbygge strategiplanlægning indenfor erhvervsliv og miljø ved at øge samarbejdet omkring forskning, udvikling og innovation.

- At styrke innovationen på områder som energieffektivisering og energiudvinding, fødevaresikkerhed og folkehelse samt at bane vejen for nordiske produkter til markeder, hvor de kan være til nytte for den stadigt voksende verdensbefolkning.

- At samenfatte resultater fra initiativer, som har tilknytning til undervisning og en bæredygtig udvikling.

- At sikre bevistheden om grøn vækst og holdbar udvikling i et langsigtet perspektiv med nye initiativer, hvor kreativitet bruges som forskningsog undervisningsmetode.

- At stimulere interessen hos de unge for forskning og universitetsarbejde på områderne bæredygtig produktion og udnyttelse af naturressourcer. 
- At forene naturvidenskab, teknik, undervisning og kultur på de forskellige skoleniveauer, institutioner og erhvervsliv.

- At udvikle en fælles nordisk platform og grundlag for samarbejde, koordinering og udveksling af idéer, på tværs af aldersgrupper og fagområder.

\section{Biophilia som undervisnings- og forskningsmetode}

Undervisnings-, forsknings- og kulturministeriets bidrag til NordBio bliver det tværfaglige undervisningsprojekt Biophilia, der sætter fokus på kreativitet som en undervisnings- og forskningsmetode. Biophilia betyder lidenskab eller kærlighed til livet og alt som lever. Det nordiske projekt opfordrer til et samarbejde mellem bl.a. børn, videnskabsmænd, lærere og kunstnere. Idéen går bl.a. ud på at integrere undervisning med kultur og videnskab i et forsøg på at opløse den traditionelle undervisningsform. Deltagerne opfordres således til at arbejde på tværs af aldersgrupper, undervisningsfag og fagområder med kreativiteten som et undervisnings- og forskningsredskab.

Natur, videnskab og kunst er forbundet på en unik måde, der kræver en holistisk tilgang. Biophilia undervisningsprojektet byder på en fælles platform og et samarbejdsgrundlag for dialog og diskussioner, der fremmer den personlige såvel som den samfundsmæssige udvikling og bidrager dermed til et bæredygtigt samfund. Projektets mål er at støtte pionertænkning og de unges interesse for videnskab, teknik og innovation i sin bredeste forstand. Inden for udformningen af Biophiliaprojektet bliver hovedvægten lagt på undervisnings- og forskningsdelen, men kultursamarbejdet samt ungdomsområdet under NORBUKs regi spiller også en stor rolle.

\section{Biophilia projekter}

\section{Undervisning og forskning}

De tre delprojekter på undervisnings- og forskningsområdet som indgår i Biophilia har alle visse fælles træk og har en stærk forankring i de nordiske programmer om Grøn vækst og Holdbar nordisk velfærd:

- Lokale samarbejdsnetværk vil blive dannet i hvert af de deltagende lande som senere danner et fælles nordisk netværk. 
- Stor vægt vil blive lagt på innovation og tværesektorielt samarbejde mellem mange forskellige partnere i hvert delprojekt.

- Færøerne, Grønland og Åland inviteres til at deltage i alle delprojekter.

- Delprojekterne defineres som treårige projekter med kontinuerligt samarbejde, som stort set deles op i en forberedelsesfase, en kick-off konference i begyndelsen af 2014, gennemførelse af projektet i 2015, og sammenfattning og evaluering af projektet i 2016.

\section{Biophilia - Distriktsamarbejde.}

Hvert deltagerland vælger et distrikt (område eller kommune) til at deltage. Desuden skal de nordiske huse og institutter på Færøerne, Grønland og Åland inviteres til at deltage i projektet. En styregruppe i hvert lands distrikt har ansvaret for gennemførelsen af projektet, dets udformning og samarbejdet med interessegrupper i eget distrikt. Disse styringsgrupper danner et nordisk netværk omkring projektet.

Hvert deltagerland/-område får eller producerer sin egen Biophilia undervisningskasse på hjul, fuld af fysik, biologi, musik og multimedia, som sendes rundt til områdets folkeskoler. Projektkassen er designet til at bryde den traditionelle undervisning op. I projektkassen findes der også undervisningsideer, som et hold nordiske eksperter har været med til at udvikle.

Undervisningsideerne kan godt blive forandret på baggrund af lokale forhold, nye erfaringer, ny viden osv. Der lægges vægt på at alle deltagere kan bidrage som de vil til projektkassen, så projektet er dynamisk og i konstant udvikling.

Målet for samarbejdet er at:

- fremme innovation i skolearbejdet ved at udvikle undervisningsmetoder som kombinerer vitenskab, kreativitet og teknologi med forskellige uddannelsesnivåer, institutioner og erhvervsliv,

- bryde den traditionelle undervisingsform op med tværfaglige angrebsvinkel på tværs af aldersgrupper, skolefag og fagområder,

- udvikle lokale samarbejdsnetværker i deltagerlandene som knyttes i et nordisk samarbejdsforum som skal arbejde for øget nordisk nytte,

- fremme de unges interesse for naturvidenskab og teknik hvorved Nordens konkurensekraft styrkes fremadrettet, 
- udvikle en web-basered arbejdsplatform uden landegrenser for et nordisk samarbejde mellem forskellige faggrupper, da projektet ophører.

\section{Biophilia - Kundskabstoget}

Kundskabstoget bygger på et projekt som Islands Universitet har udviklet i løbet af de seneste år. Målet med kundskabstoget er at rejse rundt $i$ landet med videnskab og underholdning for at vække de unges interesse for forskning og universitetsarbejde/-studier.

Kundskabstoget kan skabe en samarbejdsplatform mellem forskere og andre videnskabsmænd $i$ Norden og samtidig fremme interessen hos de unge for forskning og universitetsuddannelse. Det er vigtigt at togets besætning bruger interaktive og levende undervisningsmetoder for at formidle komplicerede emner og udfordringer på en måde, som de unge og almenheden forstår.

Idéen går ud på at Kundskabstoget rejser rundt inden for nogle specielt udvalgte nordiske distrikter med videnskabs-workshops. På hver rejse som Kundskabstoget foretager afsættes der tid for henholdsvis børnehaver, folkeskoler og de videregående skoler, hvor man tilbyder kurser i videnskab og mikro-forelæsninger. Der tilbydes også underholdning baseret på videnskab for hele familien med forskellige former for præsentation af eksperimenter og forskellige interaktive produkter og apparater fra nærliggende science-centre, tekniske museer eller innovations- og pilotforetag. På denne måde styrker man kontakter, samarbejdsplatformer og netværk inden for de forskellige områder.

\section{Biophilia - Kundskabsnet mellem videnskab og arbejdsliv}

Forudsætningen for et effektivt innovationssystem i det moderne kundskabssamfund er at der strømmer kundskab mellem virksomheder, universiteter og forskningsinstitutter. Kundskabsstrømmen kan både være systematisk og/eller uformel. Det er en konstant udfordring bedre at udnytte den viden og de økonomiske resurser, som der anvendes til innovation og udvikling. Samarbejdsnetværk, som er baseret på kundskabstriangel-konceptet har vist sig at passe godt til dette formål.

Island vil medvirke til at opbygge kundskabs-triangelnetværk, både i Norden og internationelt. Initiativets formål er bl.a. at udvikle kundskapstriangelkonceptet yderligere med fokus på at aktivere kreativitet som et værktøj. Projektet skal også fokusere på områder med spredt bebyggelse og innovationsarbejde, som er baseret på lokalt særpræg og lokale muligheder med speciel vægt på de muligheder, som findes hos områdernes kreative industrier, kunst, humaniora og sociologi. Man skal se på de erfaringer som man allerede har høstet $\mathrm{og}$ bygge videre på dem. 


\section{Kultur}

\section{Biophilia - "Arts and Audiences"}

En konference under overskriften Arts and Audiences finder sted i Reykjavik i efteråret 2014. Det forventes, at konferencens hovedtema bliver kreativitet som en undervisnings- og forskningsmetode. Derudover vil der blive fokuseret på alle former for multimedier og nye medier, hvor følgende spørgsmål søges besvaret: Hvordan kan man involvere sociale medier i kulturformidlingen? Hvordan kan man vække folks interesse og engagement ved at udnytte de nye mediers muligheder?

\section{Børn og unge}

En af de mange udfordringer, som unge står over for, er at blive lyttet til, udleve deres menneskerettigheder og opleve sig selv som en aktiv del af det omgivende samfund. Det er nødvendigt at oplyse de unge om, hvordan deres stemmer kan bliver hørt, og hvordan de kan være med til at skabe et bedre samfund. Derfor er det vigtigt, at værktøjer som øger demokrati, deltagelse og kreativitet bliver gjort tilgængelige og tilpasset de unge. Ministerrådets organ på børne- og ungdomsområdet, NORDBUK, deltager aktivt i Biophila projektet, på den ene side ved at arrangere Ungdommens folkemøde og på den anden side med deltagelse i konferencen Arts and Audiences.

\section{Ungdommens folkemøde}

Ungdommens folkemøde finder sted i Reykjavik den 5. april 2014, hvor deltagere fra samtlige nordiske lande vil blive inviteret. På mødet får de unge mulighed for frit at diskutere deres egne forhold, påvirke deres omgivelser og at gøre rede for deres idéer. Denne tilgang kræver en aktiv demokrati- og samfundsdeltagelse, kreativitet og gennemførelse af idéer. Et af mødets hovedformål er at indsamle materiale og idéer til en virtuel Biophilia værktøjskasse. Demokrati, samfundsdeltagelse og kreativitet bliver værktøjskassens hovedtema, og der skal drages fuld nytte af innovative metoder til at nå ud til de unge. Målet med værktøjskassen er at hjælpe de unge med at få deres stemmer hørt og deres ideer gjort til virkelighed. Der skal fokuseres på brugbare oplysninger om de nordiske landes politiske systemer, demokrati og samfundsdeltagelse, som f.eks. hvordan unge kan påvirke og udleve deres rettigheder i det daglige liv, og hvordan de unges stemmer kan være med til at vise vejen i det politiske system. I værktøjskassen finder man også korte videooptagelser, hvor nye muligheder undersøges i forhold til at udnytte demokrati, samfundsdeltagelse og kreativitet med henblik på at skabe et bedre samfund. Et samarbejde med Ungdommens Nordiske Råd vil være ønskeligt. 


\section{"Arts and Audience"}

Konferencens hovedopgave er at undersøge, hvordan man når ud til nye deltagere, og en af de workshops, der bliver afholdt, vil særligt omhandle muligheden for bedre at nå ud til unge. Deltagere i workshoppen vil være unge fra de samtlige nordiske lande og deres opgave vil være at udvikle og udforme værktøjskassen. 
Foruden at deltage i Biophila projektet har hver sektor sine specifikke formandskabsaktiviter på deres fagområde.

\section{Undervising og forskning}

Frem til udgangen af 2013 har Ministerrådet (MR-U) arbejdet ud fra strategien Kundskab for grøn vækst og velfærd. Resultaterne opnået under dette strategidokument bliver nu evalueret og vil give inspiration til strategien for de kommende år. Ministerrådet for Uddannelse og Forskning har drøftet, hvordan strategien - og strategidokumenterne - kan blive mere levende arbejdsdokumenter, som dels knytter an til de treårige formandsskabsprioriteringer, dels sikrer kontinuitet i de store satsninger og linier. Under det islandske formandsskab bliver det derfor en vigtigt opgave at medvirke til at formulere og vedtage en ny strategi, samt finde den rigtige form for sektorens strategidokument. Det er et udtalt ønske, at strategidokumentet skal kunne opdateres løbende, knytte an til formandskabsprogrammerne, samt vise sammenhængen mellem strategiske satsninger og sektorens budget og midler.

Islands fokusområder under formandskabsperioden indenfor undervisning og forskning baseres bl.a. på Nordisk Ministerråds programmer for Grøn vækst og Holdbar nordisk velfærd. Begge programmer lægger stor vægt på undervisning og forskning og værdien af disse i den strategiske planlægning. Samarbejde på tværs af institutioner, forskningsområder og grænser, med praktiske løsninger, vidensdannelse, innovation, velfærd og grøn vækst som ledetråde, vil styrke Norden som enhed og styrke Nordens muligheder for at bidrage til arbejdet $\mathrm{i}$ internationale fora.

Inden for undervisning og forskning har de nordiske lande forsøgt at udnytte og samordne deres resourcer, bl.a. med en effektiv brug af informationsteknik. Grøn vækst og holdbar velfærd må styrkes gennem forskning og undervisning som yderligere bidrager til innovation inden for disse vigtige områder.

Dagens samfund står foran mange udfordninger, alt fra klimaændringer til udfordringer indenfor helse- og samfundssikkerhed. Selv om udfordringerne er globale og integrerede, så er de eksisterende forskningsinstrumenter til at takle dem ofte begrænsede, både geografisk og akademisk. Derfor kræver globale udfordringer en ambitiøs samordning af forskningsinititativer, 


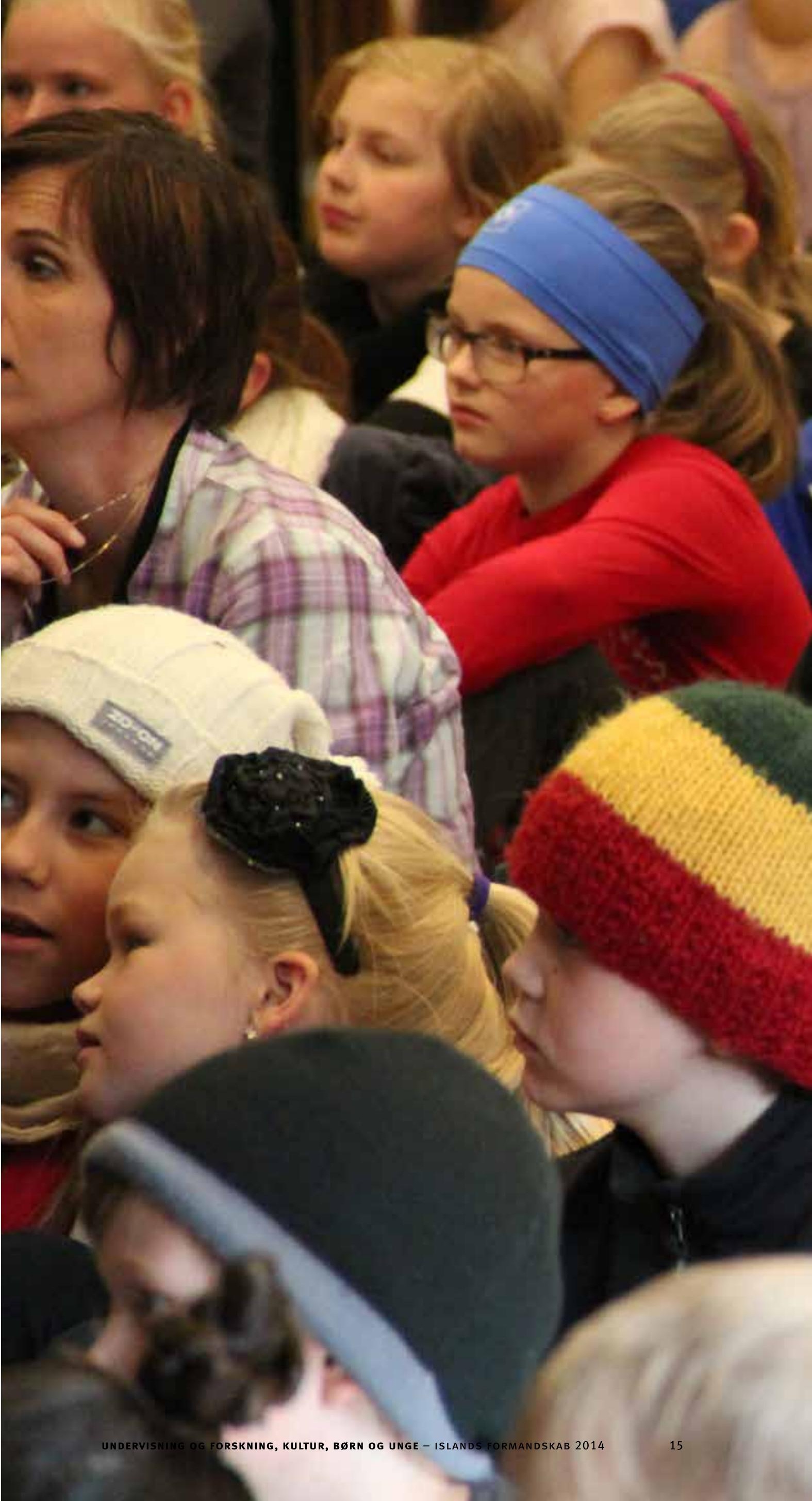


noget som allerede er til stede inden for det nordiske samarbejde. Globale problemer udtrykkes desuden i varierende grad på lokalt nivaeu, og nordisk forskningssamarbejde har derfor også det mål at styre nordisk forskning i globale problemer på den måde, at de skaber nordisk merværdi for det nordiske samfund. Under det islandske formandskab skal der arbejdes videre med Samarbejde, arbejdsdeling og koncentration (SAK) inden for universitetsområdet, som startede under Norges formandskab i 2012. Man vil også arbejde på at skaffe en permanent financering til driften af Nordic Master Program (NMP).

Der skal skabes muligheder for unge mennesker at etablere sig som forskere og arbejde for innovation på forskellige måder. Den øgede globalisering og de hurtige ændringer inden for informationsteknologi, samt de studerendes forskellige baggrund, forudsætter at uddannelserne tilpasses og udvikles både med hensyn til indhold og metodik. Kvaliteten af uddannelserne og undervisningssystemets effektivitet er baseret på fagligt kvalificerede lærere. Samfund, der ønsker at etablere sig i vidensøkonomien i det nye århundrede må se grundigt på strategier for lærergerningen og læreruddannelsen.

Den største formandskabssatsning inden undervisning og forskning er det tværfaglige Biophilia undervisningsprojekt. Derudover vil det igangsættes en række andre initiativer på hvert område for sig.

\section{Inititativer på undervisningsområdet}

\section{Lærernes professionelle udvikling}

Det er generelt et godkendt synspunkt at undervisningens kvalitet først og fremmest bygger på et veluddannet og entusiastik lærerkorps. Samfund som vil nå langt i fremtidens kundskabsøkonomi må have en tydelig politik med hensyn til lærergerningen og læreruddannelsen. Island vil under sit formandskab sætte fokus på lærernes professionelle udvikling og belyse de faktore, som støtter de nordiske lærere i at udarbejde og udvikle undervisningsmiljøer, indlæringsmiljøer og undervisningsmåder, som følger med i udviklingen inden for teknik og kultur i det 21. århundrede.

Under formandskabet vil der blive arrangeret en konference om læreres og skolelederes professionelle udvikling. Konferencen vil blive afholdt den 13. og 14. august 2014 i Reykjavik. Der vil blive sat fokus på lærerprofessionen og på at sammenligne arbejdsforholdene hos de nordiske lærere og deres muligheder for at udvikle et ambitiøst undervisningssystem som aktivt støtter et bedre nordisk velfærdssamfund i det 21. århundrede. 


\section{Voksenundervisning}

Under det islandske formandskab vil Nordisk Ministerråd og Nordisk Netværk for Voksnes Læring inviterere til en nordisk konference om Nordiske broer for livslang læring i Reykjavik den 10 og 11 juni 2014. Konferencen skal bidrage til at Ministerrådets diskussion om Holdbar nordisk velfærd løftes frem og spredes til nationale arenaer og miljøer inden for voksnes læring. For at lykkes at opnå en bærekraftig udvikling af den nordiske velfærdsmodel, som danner grundlaget for innovation, konkurrencekraft og produktivitet, kræves der et bredt engagement fra alle instanser, offentlige, private og frivillige instruktører. Arbejdsliv og undervisningssystem må satse på at bygge broer for udvikling af kompetancer og kundskab. Konferencens arbejdsmetoder skal integrere erfaringer fra Biophilia undervisningsprojektet, hvor der lægges vægt på samarbejde mellem videnskab, kultur og undervisning.

\section{Indlæring på arbejdspladsen}

Det nordiske arbejdsmarked konfronteres med mange udfordringer, som bl.a. forårsages af økonomiske problemer og ændringer i de nordiske landes demografiske sammensætning. Det er en vigtig priroritet at bekæmpe ungdomsarbejdsløsheden og at aktivere de unge, som er i fare for at blive isoleret fra arbejdsmarkedet og samfundet forøvrigt. Langtidsarbejdsløshed og relationer mellem undervisningssystemer og arbejdsmarkedet blive sat $\mathrm{i}$ fokus under det islandske formandskab.

Island inviterer til en nordisk konference om uddannelses- og studievejlednings-tilbud $i$ arbejdslivet for alle aldersgrupper. Konferencen en del af Islands deltagelse i det nordiske program Holdbar nordisk velfærd, og koncentrerer sig om den del, som handler om indlæring på arbejdspladsen, LPA. Initiativet startede under Sveriges formandskab i 2013. Konferencen organiseres i samarbejde med velfærdsministeriet i Island og afholdes den 25. september 2014.

\section{Nordisk sprog og kultur}

Nordisk Ministerråd for uddannelse og forskning og Nordisk Ministerråd for kultur deler ansvaret for sprogsamarbejdet og har nedsat en ad hoc arbejdsgruppe, som i 2014 skal drøfte anbefalinger til aktørene om hvordan sprogundervisning og kulturaktiviteter kan ses $\mathrm{i}$ sammenhæng $\mathrm{i}$ arbejdet med sprogområdet.

\section{Nordisk sprogkoordination}

Det nordiske samarbejde på sprogområdet samles fra 2014 under Foreningerne Nordens Forbund. Initiativet skal i 2014 sætte fokus på børn og unges sprogforståelse af dansk, norsk og svensk, og i særlig grad rette opmærksomheden på forståelsen af det talte sprog. Det skal også fra 2014 
i højere grad analyseres hvorvidt nordiske initiativer kan bidrage til at styrke den nationale opfølgning af sprogdeklarationen.

\section{Initiativer på forskningsområdet}

\section{Ligestilling af kønnene indenfor forskning}

De nordiske lande er kendt for deres fremskridt $i$ at opnå ligestilling mellem kvinder og mænd. Til trods for dette er andelen af kvinder i højere akademiske stillinger betydeligt lavere end for mænd, specielt inden for naturvidenskab og teknik. 80 procent af alle professorer i Norden er mænd. I 2013 udgav Nordisk Ministerråd rapporten Norden et steg nærmere kjønnsbalanse i forskning? udarbejdet af komitteen for ligestilling i forskning. En af anbefalingerne i rapporten var at etablere et netværk og udarbejde en handlingsplan for ligestilling i forskning i Norden.

Island vil under sit formandskab følge op om anbefalingen med en workshop i Reykjavik efteråret 2014. Samtidigt vil NordForsk fokusere på yderligere rekommendationer om forskningsprogrammer og statistik om ligestilling $i$ forskning i Norden.

\section{Fremme viden og kompetencer for grøn vækst}

Undervisning, forskning og innovation for grøn vækst handler om langsigtede investeringer i viden og kompetencer, der skal understøtte omstillingen til en grøn og bæredygtig økonomi. Gennem videns- og idéudvikling skal undervisning og forskning bidrage til at ændre vores adfærd, forbrug og produktion i Norden og internationalt.

For at styrke Nordens internationale førerposition og inspirere andre regioner og lande til en bæredygtig udvikling, er det vigtigt at lære af, udnytte, diskutere og profilere viden og erfaringer fra igangværende undervisnings-, forsknings- og innovationsindsatser i Norden. De nordiske lande er hver for sig for små til at kunne være ledende på mange forskningsområder. Island kommer i sin formandskabsperiode til at arbejde for at Norden fastholder sin ledende position inden for innovation og grøn vækst med langsigtede, fælles nordiske satsninger i videns- og forskningsudviklingen og en tættere kobling mellem forskning, innovation og undervisning.

I 2014 kommer Island at støtte Nordisk Ministerråds initiativ for en målrettet indsats med at formidle og profilere eksisterende viden samt nye tiltag, der kan fremme kompetencer og viden for grøn vækst i Norden og internationalt. Fokus vil sættes på at i 2014 initieres et forskningsprogram om grøn vækst forankret i NordForsk. 


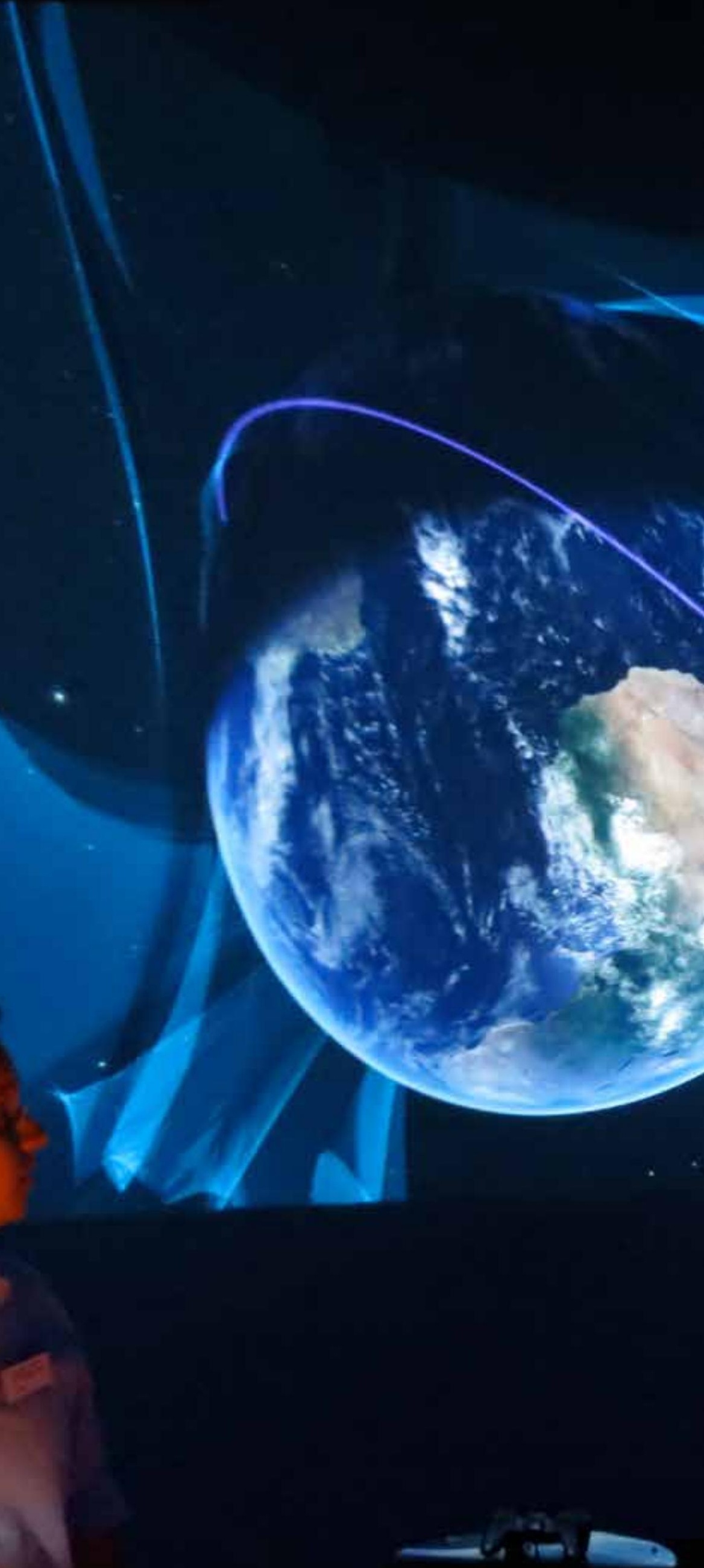




\section{Topforskningsinitiativet på klima, miljø og energi}

Verdens store klima- og energiudfordringer kræver ny kundskap og nye innovationer. Norden har gode forudsætninger for at bidrage positivt $i$ denne sammenhæng på grund af sit høje undervisningsniveau, store politisk vilje til handling og store disponible naturresourcer. Norden er allerede verdensledende indenfor flere typer fornybar energi, og dette skal der bygges videre på under toppforskningsinitiativet på klimaområdet. Toppforskningsinitiativet er en stor nordisk forsknings og innovationssatsning, som involverer både kundskabsmiljøer og næringsliv for at bidrage til at løse de globale klimaudfordringer. Under Islands formandskab kommer resultat af initiativet at bearbejdes og evalueres.

\section{Forskning for velfærd}

Inden Forskning for velfærd vil der blive gennemført en udskrivning af forskningsmidler omkring temaet social ulighed på helse og velfærd inden for rammerne af Holdbar nordisk velfærd, NordForsk's samarbejdsprogram omkring helse og velfærd. Målet er at intensificere og styrke nordisk samarbejde om forskning på socioøkonomiske forskelle i helse og velfærd og dermed fremme ny kundskab som kan bidrage til at reducere forskelle inden for helse- og velfærdssektorerne i Norden.

\section{Infrastruktur for velfærd}

Norden er pioner inden for udviklingen af registerbaserede biobanker. Inden for NordForsk's samarbejdsporgram om helse og velfærd udarbejdes der også projektet Biobanks - helse og sociale registre, som opfølgning af anbefalinger fra ekstpertgruppen NORIA-net på register. Projektet vil fokusere på at lette samarbejdsrutinerne for nordisk registerbaseret forskning. Andre rekommendationer fra ekspertgruppen inkluderer etableringen af et nordisk forskningsprogram og forslag til en ændret paksis inden for området. Rekommendationerne vil blive behandlet af NordForsk og EK-U i 2014.

\section{Holdbar udvikling i Arktis}

En stor del af Norden ligger i Arktis, som er en region af stadigt større intresse for stater og industri. På grund af den forøgede adgang til Arktis og områdets resourcer forventes der store nye muligheder til værdiskabning $i$ regionen. Samtidig er Arktis et meget ømtåleligt område, med en unik natur og sårbar kultur. NordForsk starter i 2014 et forskningsinitiativ om en holdbar udvikling i Arktis, med en planlagt udskrivning i det første halvår af 2014. Med henvisning til satsninger i bioøkonomiprogrammet vil Island under sit formandskab fokusere på dette område. Desuden vil der $\mathrm{i}$ juni 2014 blive arrangeret et Norden møder Østen seminar i Akureyri med fokus på et samarbejde om Arktis. 


\section{Nordisk forskningsinfrastruktur}

En moderne forskningsinfrastruktur er en forudsætning for en konkurrencedygtig forskning af højeste international kvalitet. Nordisk samarbejde inden for forskningsinfrastrukturer giver merværdi til nationale indsatser og investeringer gennem en forbedret kvalitet og effektivitet. Nordisk samarbejde omkring forskningsinfrastrukturer fører til mere effektiv udnyttelse af nationale resourcer og en formindsket fragmentering og kan anvendes til at samordne de nordiske interesser internationalt. Ved at udnytte deres fælles interesser har de nordiske lande et enormt potentiale for at opnå synergieffekter på dette område. Inden NordForsk findes der en rådgivende nordisk gruppe om infrastrukturer, som i 2014 vil finde og implementere passende langsigtede investeringer i eksisterende og nye forskningsinfrastrukturer.

\section{eScience}

eScience udvikler og tilpasser moderne resourcer og avancerede værktøjer inden for informationsteknik, såkaldte e-Infrastrukturer, for at avancere forskningen mere. eScience kompletterer teori og eksperiment med computerbaserede analyser af data og datasimuleringer. eScience muliggør et globalt samarbejde inden for forskning og teknik, og e-Infrastruktur har et potentiale til at blive anvendt på næsten alle forskningsområder.

Udover den førnævnte gruppe for forskningsinfrastruktur, arbejder en ad-hoc gruppe inden for eScience/e-Infrastruktur med den opgave at følge anbefalingen fra rapporten Vilja till Forskning? om at opdatere Nordisk Ministerråds handlingsplan for eScience fra 2008. Den endelig udformning af den opdaterede haldingsplan vil foregå i 2014. I efteråret 2014 vil Island arrangere en nordisk workshop om Bibliometri og forskningspolitik i Reykjavik.

\section{Forskningsprogram om sprog og sprogkultur}

En øget globalisering indebærer nye udfordringer på området sprog og sprogkultur. Forskningen i sprog, sprogkultur og kommunikation i de nordiske lande er nødvendig for bedre at kunne forstå sprogets oprindelse, udvikling og fremtidige forandringer. Som svar på disse udfordringer har NordForsk etableret et NORIA-net om nordiske sprog, sprogkultur og kommunikation, som vil unders $ø$ ge mulighederne for at etablere et nordisk forskningsprogram på området. 


\section{Kultur}

En strategi for det nordiske kultursamarbejde 2013-2020 er blevet godkendt af de nordiske kulturministre (MR-K). Samarbejdet i denne periode præges af fem hovedprioriteringer. De er som følger:

- Det bæredygtige Norden hvor nordisk kulturliv skal styrke bærekraften i de nordiske samfund ved at være tilgængeligt og involverende.

- Det kreative Norden hvor Norden skal fremstå som en levende, dynamisk og kreativ kulturregion.

- Det interkulturelle Norden hvor alle indbyggere i Norden skal føle sig hjemme og deltage i kulturlivet.

- Det unge Norden hvor børn og unge i Norden skal skabe, deltage i og have meninger om kunst og kultur.

- Det digitale Norden hvor nordisk kultur kan drage fuld nytte af den digitale teknologi.

Det islandske formandskabs projekter vil i høj grad fokusere på denne strategi. Derudover vil man prioritere Nordens internationale samarbejde, fremfor alt i UNESCOs regi, og styrke det vestnordiske samarbejde.

\section{Det bæredygtige Norden}

For at møde de nordiske velfærdsamfunds udfordringer er det nødvendigt at se på helheden og tage hensyn til de enkelte fagområder og emneområder. Natur, videnskab og kunst er forbundet på en unik måde, der kræver en holistisk tilgang.

Biophilia byder på en fælles platform og et samarbejdsgrundlag for dialog og diskussioner, der fremmer den personlige såvel som den samfundsmæssige udvikling og bidrager dermed til et bæredygtigt samfund.

Klima- og miljøændringer påvirker i høj grad den bæredygtige udvikling såvel som menneskehedens fremtid. Viden om disse essentielle temaer når som regel ikke fra videnskabssamfundet ud til offentligheden. Island vil se på, hvordan man kan drage nytte af et samarbejde mellem forskere og unge kunstnere med henblik på at formidle data til den almene borger i Norden. 
Kultur og kulturens bidrag til samfundet kan have en afgørende betydning for folkesundheden og udviklingen af bæredygtige samfund. Sveriges formandskab satte fokus på succeshistorier i de nordiske lande, og hvordan man i så fald kunne følge op på dem i det nordiske samarbejde. Island agter at fortsætte denne kurs.

\section{"Connect" - et nordisk samarbejdsprojekt mellem kunst og videnskab}

Forskere mødes med unge kunstnere for at diskutere, hvordan et samarbejde mellem kunst og videnskab kan etableres. Formålet med dette er at støtte forskerne i at formidle deres resultater og anbefalinger til offentligheden på en begribelig måde. En workshop vil blive arrangeret i efteråret 2014.

\section{Project 7}

Et internationalt projekt hvor en gruppe unge nordiske kunstnere og forskere under 40 år samarbejder tværfagligt i fire workshops i fire lande (henholdsvis Grønland, Island, Finland og Norge). En udstilling vil blive arrangeret $i$ Sverige i 2015. Udstillingen er tænkt som et univers, hvor man træder indenfor og oplever, hvordan verden vil kunne udvikle sig i løbet af syv generationer, hvis der sker en radikal kursændring i finanssektoren i retning af øget bæredygtighed og inkludering.

\section{Kultur og helse}

De nordiske kulturministre (MR-K) vedtog på deres møde i april 2013 at igangsætte en udredning om kultur og sundhed. Igangværende og gennemførte projekter skal kortlægges, og nordisk og international forskning på området vil blive gennemgået. Resultaterne fremlægges på kulturministrenes møde i efteråret 2014.

\section{Det kreative Norden}

Norden samarbejder om en styrkelse af de kreative erhverv på mange områder, f.eks. inden for KreaNord, og ved at bidrage til udviklingen af Den Nordlige Dimensions Kulturpartnerskab. Det islandske formandskab sætter fokus på musik og design. Island vil fortsat arbejde for, at man øger den nordiske støtte til de kreative erhverv, bl.a. via det nye KreaNord støtteprogram i perioden 2013-2015. Projektet har ført til et tværfagligt samarbejde mellem erhvervslivet og kulturindustrien, og der råder enighed om, at vægten af og behovet for et nordisk samarbejde af denne art er væsentlig, ikke mindst mellem de ministerier og institutioner der har ansvar for nærværende emneområder.

\section{Den nordiske spilleliste}

Den nordiske spilleliste er et af de prioriterede projekter under det islandske formandskab. Dette nordiske samarbejdsprojekt er et af de formandskabs- 
projekter, der vil få en bevilling til en periode på tre år. Projektet skal styrke det nordiske marked for populærmusik fra de nordiske lande, gøre opmærksom på nordiske kunstnere og grupper, øge eksportmulighederne for nordisk musik, registrere nordisk populærmusik i takt med dennes udvikling samt drage nytte af det nordiske samarbejdes potentiale på området.

\section{Den nordiske modebiennale i Frankfurt 2014}

Den tredje nordiske modebiennale finder sted i Frankfurt i Tyskland i perioden 21. marts til 26. juni 2014. Den første biennale blev afholdt i Reykjavik i 2009 efterfulgt af Seattle i 2011. Den nordiske biennale i Frankfurt sætter fokus på færøsk, grønlandsk og islandsk kunst og modedesign med hovedvægt på kunstnere og modedesignere fra de tre lande. Arrangementet skal synliggøre kreative talenter fra de vestnordiske øer og bane vejen for dem i udlandet. Den nordiske modebiennale består af en udstilling og en konference, og i 2014 bliver der for første gang udgivet en bog i tilknytning hertil, som vil uddybe projektet yderligere. Udstillingen åbner i København i slutningen af 2014. Bag arrangementet står Nordens Hus i Reykjavik og Museum Für Angewandte Kunst i Frankfurt.

\section{Det interkulturelle Norden}

Det nordiske samarbejde består bl.a. af et tværkulturelt samarbejde mellem forskellige grupper, hvor der tages højde for alle aldersgrupper.

Samarbejdets særstilling skyldes bl.a. de stærke historiske og kulturelle bånd mellem landene, som fortsat bliver holdt ved lige gennem et samarbejde mellem amatørforeninger og en folkelig deltagelse. Det samme gælder for det meget værdifulde græsrodssamarbejde på kultur- og kunstområdet, hvor foreningerne står bag adskillige former for nordiske samarbejdsprojekter. Det bør sikres at samarbejdet styrkes og at projekter med støtte fra nordiske støtteprogrammer får en større synlighed der kan inspirere til nye samarbejdsinitiativer.

Hvad man i ungdommen nemmer, det man i alderdommen ej forglemmer - konference om det frie foreningsliv og de æeldres rolle

I mange tilfælde udgør midaldrende og ældre borgere hovedbestanddelen af det samfundssegment, der forbruger kultur, og samtidig er det denne gruppe, der i de fleste tilfælde bærer det frie foreningsliv oppe. Den viden og kultur, der opstår i foreningslivet, er uvurderlig. Derfor er den vigtig at værne om og formidle videre til de yngre generationer, uden at de ældre bliver skubbet af banen. Det islandske formandskab vil arrangere en konference med fokus på, hvordan man bevarer den viden, som deltagerne i det frie foreningsliv besidder, og hvordan man kan formidle den videre til de yngre generationer. I næsten hundrede år har Foreningen Norden spillet en vigtig rolle i forhold til 


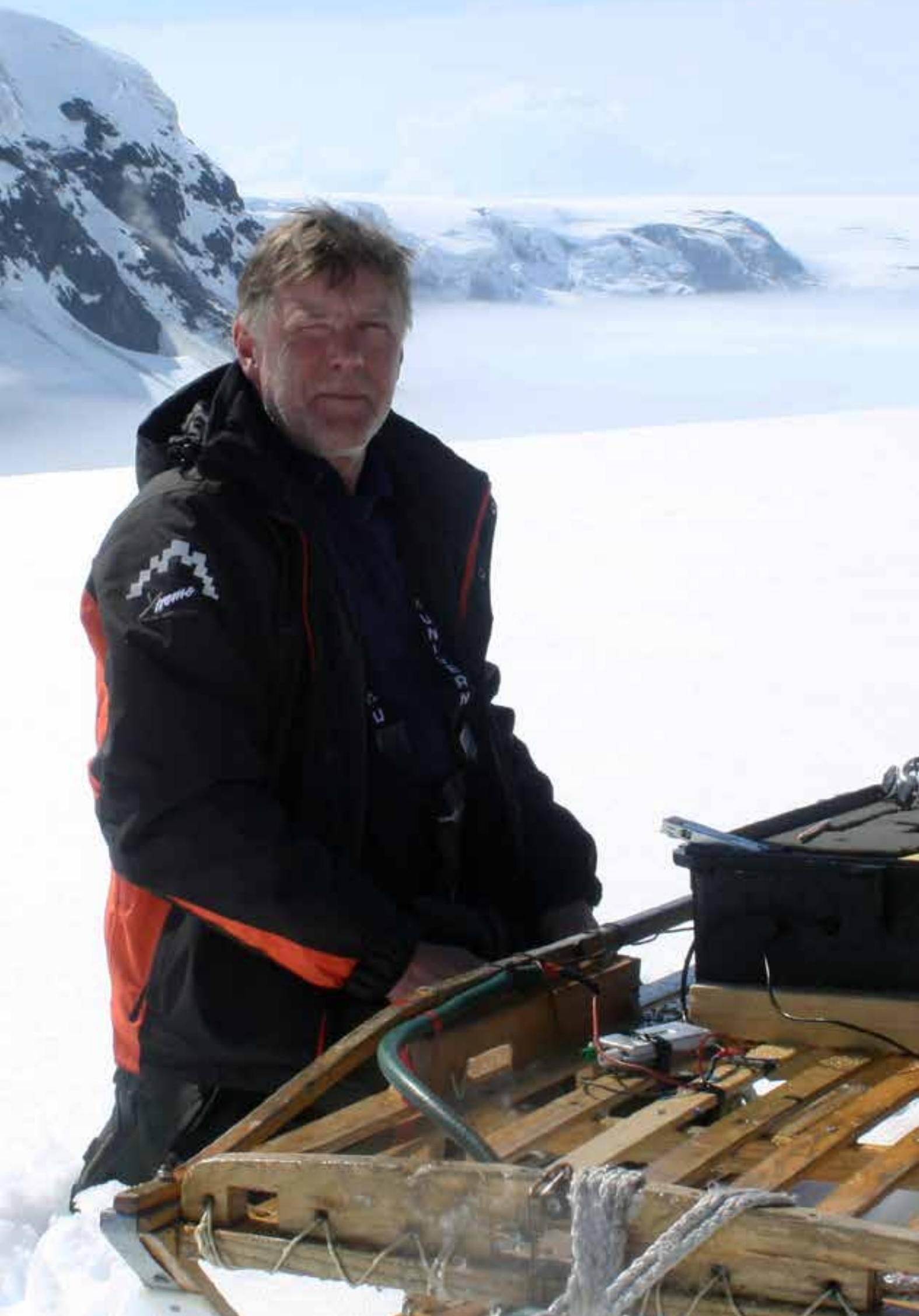


at styrke det nordiske samarbejde. Derfor har det islandske formandskab kontaktet Foreningen Norden med henblik på et samarbejde om konferencen.

\section{Det unge Norden}

Børn og unge er et af de prioriterede områder i det nordiske samarbejde, hvilket bl.a. fremgår af strategierne for de mange samarbejdsområder, herunder det kulturelle samarbejde. Undervisning og demokratisk medvirken er grundlaget for en bedre livskvalitet.

Nordisk Råds børne- og ungdomslitteraturpris blev uddelt for første gang $\mathrm{i}$ oktober 2013. Dermed ønsker Nordisk Råd at understrege betydningen af børne- og ungdomslitteratur i Norden. Som en opfølgning er der planer om en årlig omfattende festival om børne- og ungdomslitteratur i Island. Den første festival vil blive afholdt i efteråret 2014.

\section{Unges kunstworkshop - Nordisk Lys 2014}

En nordisk kulturfestival for unge i alderen 14-17 år. 75 unge kunstrere samles på 15 forskellige steder i Norden med henblik på at arbejde sammen med kunstnere. Festivalen omfatter fem forskellige kunstarter; dans, visuel kunst, teater, cirkus og musik. Nordisk Lys 2014 er den mest omfattende kulturfestival for unge, der nogensinde er afholdt i Norden, og samtidigt det allerstørste kulturprojekt for unge som Nordisk Kulturfond og dermed Nordisk Ministerråd har stået bag. Festivalen bliver Årets Nordiske Kulturbegivenhed i 2014.

\section{Børne- og ungdomslitteraturfestival i Island}

I anledning af den nordiske børnebogspris arrangeres en nordisk børne- og ungdomslitteraturfestival i Island i efteråret 2014. De forfattere og illustratører, der bliver nomineret til prisen i 2014, bliver inviteret. Festivalen sætter dermed fokus på moderne nordisk børne- og ungdomslitteratur, men derudover er det også intentionen at invitere endnu flere forfattere og illustratorer fra andre lande. Ambitionen er, at litteraturfestivalen skal etablere sig som en stor kulturbegivenhed for islandske børn i hele landet. Festivalen fokuserer på tre områder: Læserskaren (børn og unge), forfattere og kunstnere og akademikere.

\section{Det digitale Norden}

Den digitale teknologi skaber adskillige muligheder for Norden og gør det muligt at opnå fælles erfaringer knyttet til kultur og sprog. Digital formidling er en vigtig metode til at sikre tilgang til og viden om nordisk kunst og kultur. Det er også et vigtigt led i forhold til at demokratisere adgangen til kultur og 
kulturarv samt til at videreformidle den fælles kulturarv og bidrage til en nordisk samhørighed. Island vil bl.a. lægge vægt på at arbejde for en forbedring af offentlighedens adgang til kilder og data, der opbevares i de nordiske landes rigsarkiver. Derudover bliver der gjort en indsats for at præsentere den fælles nordiske kulturarv som findes i de islandske sagaer der udkommer i en ny oversættelse på henholdsvis dansk, norsk og svensk i foråret 2014. Udgivelsen kobles til det fokus, der er på sprog og den forstærkede sprogbevidsthed i de nordiske lande.

\section{En nordisk webportal for rigsarkiverne}

Rigsarkiverne i de nordiske lande har haft et godt samarbejde gennem flere årtier. Nu planlægger de et samarbejde om etableringen af en fælles webportal eller webside med henblik på at øge rigsarkivernes synlighed i cyberspace og øge offentlighedens adgang til data i arkiverne. Det islandske formandskab vil sætte fokus på dette samarbejde og lægge vægt på at styrke det.

\section{Præsentation af de islandske sagaer på henholdsvis dansk, norsk og svensk}

I foråret 2014 udkommer den samlede islandske sagaskat i dansk, norsk og svensk oversættelse. Der er tale om verdenslitteratur og en vigtig kulturarv, som Norden har til fælles. Det akademiske og kunstneriske aspekt er fremtrædende i disse nye og højt kvalificerede oversættelser. Oversættelses- og redigeringsarbejdet har pågået i mange år, hvor oversættere, akademikere og forfattere i de nordiske lande har samarbejdet på tværs. Projektet har modtaget en betydelig finansiel støtte i de lande, der er involveret i udgivelserne. Denne solide og moderne sagasamling præsenterer bl.a. nogle sagaer for første gang i en skandinavisk oversættelse.

Islands formandskab agter at formidle dette store arbejde til Nordens indbyggere. Udgivelsen bliver markeret den 28. april 2014 med en konference i tilknytning til de nordiske kulturministres møde i Reykjavik. Formandskabsåret afsluttes med et seminar, hvor udgivelsen af sagaerne knyttes til Nordisk Ministerråds sprogkampagne, og hvor man drøfter, hvordan sagaerne kan formidles til den unge generation. 


\section{Internationalt samarbejde i et nordisk perspektiv}

De nordiske lande har en lang tradition for at arbejde sammen i internationale fora. Ikke mindst inden for rammerne af UNESCO. Således støtter landene hinanden, når et af dem kandiderer til et tillidshverv inden for organisationen. UNESCO delegationerne i de nordiske lande arbejder tæt sammen og mødes regelmæssigt til samråd et par gange om året. Norden samarbejder også tæt om sager knyttet til UNESCOs Verdensarvskonvention, bl.a. inden for rammerne af Den nordiske verdensarvsstiftelse (NWHF) i Oslo og netværket for nordiske verdensarvsområder. Islands formandskab prioriterer dette samarbejde ved bl.a. at fokusere på konventioner og initiativer knyttet til UNESCO.

\section{Konference med fokus på UNESCOs konvention om den immaterielle kulturarv.}

Morgendagens traditioner er overskriften på en konference om kulturarv og immateriel arv i forbindelse med UNESCOs konvention om immateriel kulturarv, initieret af Nordisk Folkmusikkommitté (NFC). Forsknings- og udviklingscentret på Akureyri Universitet står for den praktiske tilrettelæggelse i et samarbejde med Stemma - Landssamtök kvæðamanna (kvædesangernes landsforbund), Vilhjálmur Stefánssons Arktiske Institut, Forskningscentret for Musikvidenskab ved Islands Universitet og Nordisk Folkmusikkomité. På konferencen vil man bl.a. drøfte implementeringen af konventionen i de nordiske lande, indspil om samarbejde og koordinering samt gode eksempler. Konferencen finder sted den 20.-23. august 2014 i Akureyri.

\section{Nominering af vikingeminder til UNESCOs liste over verdensarv}

I løbet af de senere år har fem lande, heriblandt tre nordiske lande under Islands ledelse, arbejdet på at forberede en international nominering af vikingeminder til UNESCOs verdensarvsliste. Nomineringsdokumentet bliver afleveret på UNESCOs verdensarvcenter i Paris i slutningen af januar 2014. Nomineringsprocessen har skabt stor opmærksomhed bl.a. på grund af den helt nye indfaldssvinkel til opgaven. Islands formandskab vil arbejde for, at dette samarbejde bliver præsenteret og synliggjort i og uden for Norden.

\section{Vestnordisk samarbejde}

I en gældende samarbejdsaftale mellem Færøerne, Grønland og Island lægges der vægt på øget samarbejde om kultur, undervisning og forskning. Hvert land har påtaget sig et ansvar for konkrete projekter, hvor Island vil sørge for at igangsætte to projekter; dels et projekt om undervisning, der fremmer bæredygtig udvikling, og dels et projekt om udvikling af et kontaktnet og støttemuligheder for kunstnere og kulturarbejdere. 
Konference om bæredygtig undervisning uden for det formelle undervisningssystem

Grønland har påtaget sig at afholde en konference om bæredygtig undervisning uden for undervisningssystemets rammer med en præsentation af projekter, som unge selv har gennemført. Konferencen var planlagt i 2013, men måtte udsættes. Islands formandskab vil benytte lejligheden til at støtte Grønland $i$ at afholde konferencen enten i foråret eller efteråret 2014.

\section{Styrket kontaktnet for vestnordiske kunstnere og kulturarbejdere}

Der planlægges et seminar for at drøfte etableringen af et kontaktnet og oplyse om støtteordninger for vestnordiske kunstnere og kulturarbejdere.

\section{Vestnordisk filmsamarbejde}

I oktober planlægges et seminar i Island, hvor film- og programredaktører fra Danmark, Færøerne, Grønland og Island samt det øvrige Norden får mulighed for at lære hinanden at kende, formidle erfaringer, knytte kontakter og etablere et samarbejde.

\section{Børn og unge}

NORDBUKs projekter i 2014 bygger dels på Nordisk Ministerråds Strategi for børn og unge i Norden fra 2010, Handlingsplanen for Nordisk Børne- og Ungdomskomite 2010-2013 samt Islands formandskabsprogram for 2014.

Børn og unge er et af de prioriterede områder i nordisk samarbejde. Det er Nordisk Ministerråds erklærede mål på børne- og ungdomsområdet, at Norden skal være det bedste sted i verden for børn og unge.

Nordisk Ministerråds (NMR) strategi for børn og unge i Norden fra 2010 er retningsgivende for de samlede aktiviteter, ministerrådet driver over for børn og unge. Med baggrund i strategien udarbejder NORDBUK en handlingsplan. Under det svenske formandskab har man gennemført et fagligt og velovervejet arbejde med NORDBUKs projekter og fremtidsvision, der er blevet fremlagt $i$ en handlingsplan, som gælder for perioden 2014-2017. Handlingsplanen afventer MR-SAMs godkendelse.

Det islandske formandskab vil inden for NORDBUK arbejde for unges og deres organisationers aktive deltagelse i undervisningsprojektet Biophilia.

En af den nordiske velfærdsmodels udfordringer er demokrati og unge menneskers aktive deltagelse i samfundet. Uddannelse og deltagelse i et demokratisk 
arbejde er fundamentalt for livskvalitet og ligestilling. Der har pågået mange diskussioner om det nordiske samarbejdes fremtid, og hvordan dette skal udvikle sig fremover. En af NORDBUKs vigtigste opgaver er at øge deltagelse i demokratiet, hvilket der gøres rede for i udkastet til NORDBUKs handlingsplan 2014-2017. Unge menneskers nedadgående interesse for demokrati og deltagelse heri giver anledning til bekymring og kræver nye tilgange til, hvordan man når ud til dem. Gennem nyskabende metoder skal demokratiet således styrkes, og unge menneskers ret til at påvirke deres nærmiljø sikres.

Undervisningsprojektet Biophilia byder netop på sådanne muligheder. Her bestræber man sig på at bryde med den traditionelle tilgang og se udfordringerne fra flere sider. NORDBUKs opgave inden for rammerne af Biophilia-projektet er at udvikle en elektronisk værktøjskasse, der indeholder værktøjer og beskrivelser af metoder til at styrke demokrati samt $ø$ ge unges kreativitet og aktive medvirken i samfundet. En gruppe unge har indledt en kritisk gennemgang af forskellige metoder til at støtte unge menneskers deltagelse i samfundet og påbegyndt arbejdet med konstruktionen af den omtalte værktøjskasse. Værktøjskassen bliver præsenteret separat i forbindelse med Biophilia - kundskabstoget.

\section{Tværfagligt samarbejde}

En af NORDBUKs opgaver er at styrke et tværfagligt samarbejde og integrere børne- og ungeaspektet i samtlige af Nordisk Ministerråds samarbejdsområder. I et udkast til NORDBUKs handlingsplan foreslås en arbejdsform, som man med fordel kan udvikle næste år samtidig med en revision af arbejdsmetoder og arbejdsgange. Blandt andet er det nødvendigt, at NORDBUK vedtager prioriteringer og mål i overensstemmelse med handlingsplanen. Det er vigtigt, at komitéen løbende informeres om børn og unges forhold, så denne viden kan videreformidles til Nordisk Ministerråd.

\section{Egne projekter}

For at bidrage til at det overordnede mål i strategien bliver opfyldt, skal NORDBUK i tillæg til sin tværsektorielle virksomhed også arbejde med flere egne projekter på en række prioriterede områder, som falder uden for de øvrige fagområder i NMR. Hovedopgaven i 2014 er at tilpasse og koordinere NORDBUKs arbejde med den nye handlingsplan.

\section{Forskningskoordinator}

NORDBUK har siden 2012 haft en forsker som forskningskoordinator i en $50 \%$ ansættelse. Forskningskoordinatoren har til opgave at være med til at indsamle, systematisere og formidle viden om børn og unge fra aktuel forskning med særlig fokus på temaer som unges arbejdsløshed og marginalisering. I 2014 skal forskningskoordinatorens ansættelse revideres. 

norden

\section{Nordisk Ministerråd}

Ved Stranden 18

DK-1061 København K

www.norden.org

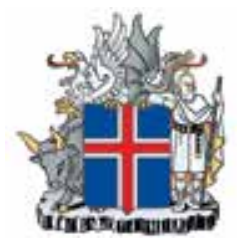

Yderligere information om Islands formandskab i Nordisk Ministerråd fås på www.norden2014.is og www.nordic2014.com.

Udenrigsministeriet Nordisk sekretariat Raudarárstígur 25 IS-105 Reykjavík Island

Telefon: +3545459900 